\title{
YKL-40 as a new promising prognostic marker of severity in COVID infection
}

\author{
Lauranne Schoneveld ${ }^{1}$, Aurélie Ladang ${ }^{1}$, Monique Henket ${ }^{2}$, Anne-Noëlle Frix ${ }^{2}$, Etienne Cavalier ${ }^{1 *+}$ (i) \\ and Julien Guiot ${ }^{2 \dagger}$ on behalf of the COVID-19 clinical investigators of the $\mathrm{CHU}$ de Liège
}

Keywords: COVID-19, SARS-CoV-2, YKL-40, Chitinase 3-like 1, Interstitial lung disease

The severe acute respiratory syndrome coronavirus 2 (SARS-CoV-2) is responsible for a disease named COVID-19, which may be associated with common symptoms or lead patients to intensive care unit (ICU) or death. The severity of the disease is mainly driven by diffuse interstitial lung diseases (ILD). YKL-40 has a promitogenic action on pulmonary fibroblasts, increases the activity of macrophages and is associated with inflammatory disorders, arteriosclerosis and endothelial dysfunction. In ILD, YKL-40 has been described to be associated with the severity of lung diseases and with the risk of death [1-6]. Yet, in COVID-19 infection, YKL-40 serum levels could therefore be of interest for diagnosis and prognosis since it is at the cross-link between vascular and epithelial lung damage, which are typical characteristics of COVID-19 infection. By closing the gap between those two pathological characteristics, we thought that YKL-40 could be of interest a specific biomarker of severe COVID-19 infection.

We thus retrospectively compared serum levels of YKL40 in a cohort of 103 patients infected by SARS-CoV-2 hospitalized between March 1 and April 29, 2020, with a group of 58 appariated healthy subjects (HS), 26 patients suffering from chronic obstructive pulmonary disease (COPD) and 53 from non-COVID ILD. Measurement of YKL-40 was taken with the MicroVue ${ }^{\mathrm{TM}}$ YKL-40 enzyme immunoassay kit during the 3 first days of admission and

\footnotetext{
*Correspondence: etienne.cavalier@chuliege.be

${ }^{\dagger}$ Etienne Cavalier and Julien Guiot have contributed equally to this work

${ }^{1}$ Department of Clinical Chemistry, University of Liege, CHU de Liège, Domaine Universitaire du Sart-Tilman, B35, 4000 Liège, Belgium

Full list of author information is available at the end of the article
}

retrospectively analyzed and correlated the results with clinical data [ICU admission, acute renal failure (ARF) or multiple organ failure (MOF)].

Median age of COVID-19 positive patients was 69 yo with a male predominancy $(67 \%)$. A significant proportion of the cohort $(n=103)$ experienced ICU admission (30\%), ARF (32\%) and MOF (28\%).

COVID-19 patients who were admitted in ICU had statistically higher CRP, creatinine, LDH and YKL-40 $(p<0.05)$ (Table 1$)$. The lymphocyte count was not statistically lower $(p=0.059)$ and D-dimers were not higher ( $p=0.1297)$ compared to the other group.

COVID-19 patients exhibited higher serum levels of YKL-40 than HS, COPD and ILD $(p<0.0001$ for all groups) (Fig. 1). Median serum level of YKL-40 was $206 \mathrm{ng} / \mathrm{ml}$ (95-431) in the COVID-19 group, $46 \mathrm{ng} / \mathrm{ml}$ (34-67) in the HS subgroup, whereas they were of $60 \mathrm{ng} /$ $\mathrm{ml}(41-73)$ in the COPD and $73 \mathrm{ng} / \mathrm{ml}(42-91)$ in the ILD groups, respectively.

Patients suffering from more severe diseases had significantly higher YKL- 40 values than those who did not experience ICU admission, MOF or ARF $(p<0.05$, $p<0.05, p<0.001$, respectively). Patients infected by COVID-19 suffering from prior chronic renal failure and chronic cardiopathy were exhibiting an increased serum level of YKL-40 ( $p<0.0001$ and $p<0.001$, respectively). Death was not statistically correlated to levels of YKL-40 within the COVID-19 patient group ( $p=0.12$ ).

The area under the ROC curve (AUC) for the discrimination of patients admitted or not to the ICU in association with the levels of YKL-40, the age and the percentage of lesions visible on the thoracic scanner

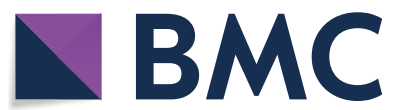

(c) The Author(s) 2021. Open Access This article is licensed under a Creative Commons Attribution 4.0 International License, which permits use, sharing, adaptation, distribution and reproduction in any medium or format, as long as you give appropriate credit to the original author(s) and the source, provide a link to the Creative Commons licence, and indicate if changes were made. The images or other third party material in this article are included in the article's Creative Commons licence, unless indicated otherwise in a credit line to the material. If material is not included in the article's Creative Commons licence and your intended use is not permitted by statutory regulation or exceeds the permitted use, you will need to obtain permission directly from the copyright holder. To view a copy of this licence, visit http://creativecommons.org/licenses/by/4.0/. The Creative Commons Public Domain Dedication waiver (http://creativeco mmons.org/publicdomain/zero/1.0/) applies to the data made available in this article, unless otherwise stated in a credit line to the data. 
Table 1 Comparison between COVID-19 patients admitted to intensive care or not

\begin{tabular}{|c|c|c|c|}
\hline Variables & ICU, No $(n=72)$ & ICU, Yes $(n=31)$ & $p$ value \\
\hline Age (year) & $71(58-82)$ & $65(59-69)$ & $<0.05$ \\
\hline Gender M/F & $44 / 28$ & $22 / 9$ & NS \\
\hline Height (cm) & $169(162-176)$ & $175(169-180)$ & $<0.05$ \\
\hline Weight (kg) & $71(63-84)$ & $96(80-105)$ & $<0.0001$ \\
\hline $\mathrm{BMI}\left(\mathrm{kg} / \mathrm{m}^{2}\right)$ & $25(22-29)$ & $31(27-34)$ & $<0.0001$ \\
\hline Abnormal lung lesions (\%) & $20(10-35)$ & $40(30-50)$ & $<0.001$ \\
\hline SpO2 (\%) & $93(89-96)$ & $88(75-90)$ & $<0.0001$ \\
\hline Death, No/Yes (\%) & $92.8 / 7.2$ & $89.3 / 10.7$ & NS \\
\hline Shock or organ failure, No/Yes (\%) & $91.3 / 8.7$ & $26.7 / 73.3$ & $<0.0001$ \\
\hline Cardiopathy, No/Yes (\%) & $85.5 / 14.5$ & $75 / 25$ & NS \\
\hline ARF, No/Yes (\%) & $79.7 / 20.3$ & $40 / 60$ & $<0.001$ \\
\hline CRF, No/Yes (\%) & $85.5 / 14.5$ & $96.7 / 3.3$ & NS \\
\hline Diabetes, No/Yes (\%) & $85.5 / 14.5$ & $62.1 / 37.9$ & $<0.05$ \\
\hline Red blood cells $(\times 10 \mathrm{e} 6 / \mu \mathrm{l})$ & $4.29 \pm 0.79$ & $4.48 \pm 0.85$ & NS \\
\hline Hematocrit (\%) & $38 \pm 7$ & $39 \pm 7$ & NS \\
\hline Hemoglobin (g/dl) & $13 \pm 2$ & $14 \pm 2$ & NS \\
\hline Globular volume (fl) & $89 \pm 8$ & $89 \pm 7$ & NS \\
\hline Reticulocytes (\%) & $0.97(0.72-1.15)$ & $1(0.57-1.04)$ & NS \\
\hline Reticulocytes $\left(\times 10^{3} / \mu \mathrm{l}\right)$ & $39(29-50)$ & $39(24-51)$ & NS \\
\hline Leucocytes $(\times 10 \mathrm{e} 3 / \mu \mathrm{l})$ & $6.15(4.63-8.03)$ & $7.87(4.91-13.54)$ & $<0.05$ \\
\hline Blood neutrophils (\%) & $73 \pm 12$ & $78 \pm 17$ & $<0.05$ \\
\hline Blood lymphocytes (\%) & $15(10-24)$ & $10(5-20)$ & $<0.05$ \\
\hline Blood monocytes (\%) & $0.2(0-0.9)$ & $0(0-0.1)$ & $<0.01$ \\
\hline Blood eosinophils (\%) & $7.73 \pm 4.36$ & $5.63 \pm 3.32$ & NS \\
\hline Blood basophils (\%) & $0.2(0.2-0.4)$ & $0.2(0.1-0.3)$ & NS \\
\hline Blood neutrophils $\left(10^{3} / \mu \mathrm{l}\right)$ & $4.54(3.07-6.4)$ & $6.96(3.5-11.73)$ & $<0.05$ \\
\hline Blood lymphocytes $\left(10^{3} / \mu l\right)$ & $0.96(0.69-1.27)$ & $0.73(0.59-1.12)$ & NS \\
\hline Blood monocytes $\left(10^{3} / \mu \mathrm{l}\right)$ & $0.42(0.25-0.6)$ & $0.37(0.27-0.6)$ & NS \\
\hline Blood eosinophils $\left(10^{3} / \mu l\right)$ & $0.01(0-0.05)$ & $0(0-0.01)$ & $<0.05$ \\
\hline Blood basophils $\left(10^{3} / \mu \mathrm{l}\right)$ & $0.01(0.01-0.02)$ & $0.02(0.01-0.03)$ & NS \\
\hline Platelets $\left(10^{3} / \mu \mathrm{l}\right)$ & $195(157-266)$ & $189(155-252)$ & NS \\
\hline Quick time (\%) & $83 \pm 22$ & $83 \pm 13$ & NS \\
\hline Quick time (s) & $13(12-13)$ & $13(12-13)$ & NS \\
\hline Fibrinogen (g/l) & $5.24 \pm 1.61$ & $6.06 \pm 2.01$ & NS \\
\hline D-dimers $(\mu g / L)$ & $876(517-1787)$ & $1483(586-2422)$ & NS \\
\hline Erythrocytes sedimentation rate $(\mathrm{mm} / \mathrm{h})$ & $123(123-123)$ & $48(48-48)$ & NS \\
\hline Iron $(\mu \mathrm{mol} / \mathrm{l})$ & $4.27(2.95-7.36)$ & $4.61(3.35-7.06)$ & NS \\
\hline Ferritin $(\mu \mathrm{g} / \mathrm{l})$ & $827(499-1677)$ & $1861(889-4117)$ & $<0.05$ \\
\hline Osmolality (mosm/kg) & $290 \pm 15$ & $286 \pm 11$ & NS \\
\hline Sodium (mmol/l) & $139 \pm 5$ & $136 \pm 4$ & $<0.05$ \\
\hline Chlorides (mmol/l) & $102 \pm 6$ & $100 \pm 5$ & NS \\
\hline Potassium (mmol/L) & $4.04 \pm 0.44$ & $4.16 \pm 0.62$ & NS \\
\hline Calcium (mmol/l) & $2.23 \pm 0.18$ & $2.14 \pm 0.21$ & NS \\
\hline Phosphates (mg/l) & $0.99 \pm 0.2$ & $1.15 \pm 0.34$ & NS \\
\hline Bicarbonates $(\mathrm{mmol} / \mathrm{l})$ & $24(21-26)$ & $23(19-26)$ & NS \\
\hline Creatinine (mg/dl) & $0.93(0.8-1.31)$ & $1.25(0.88-1.6)$ & 0.05 \\
\hline Urea (mg/dL) & $41(31-68)$ & $53(40-84)$ & $<0.05$ \\
\hline GFR (MDRD) (ml/min/1.73m²) & $71 \pm 33$ & $60 \pm 30$ & NS \\
\hline Total protein $(\mathrm{g} / \mathrm{l})$ & $66 \pm 8$ & $66 \pm 11$ & NS \\
\hline
\end{tabular}


Table 1 (continued)

\begin{tabular}{|c|c|c|c|}
\hline Variables & ICU, No $(n=72)$ & ICU, Yes $(n=31)$ & $p$ value \\
\hline Albumin (g/l) & $37 \pm 5$ & $36 \pm 4$ & NS \\
\hline Uric acid (mg/dl) & $61 \pm 25$ & $63 \pm 25$ & NS \\
\hline $\mathrm{CRP}(\mathrm{mg} / \mathrm{l})$ & $58(26-144)$ & $166(105-265)$ & $<0.0001$ \\
\hline Total bilirubin (mg/dl) & $0.62(0.44-0.82)$ & $0.79(0.53-1.02)$ & $<0.05$ \\
\hline Conjugated bilirubin (mg/dl) & $0.25(0.18-0.34)$ & $0.33(0.25-0.5)$ & $<0.05$ \\
\hline Alkaline phosphatase (U/I) & $75(59-90)$ & $70(57-95)$ & NS \\
\hline GGT $(\mathrm{U} / \mathrm{I})$ & $52(30-111)$ & $64(29-133)$ & NS \\
\hline $\operatorname{ASAT}(\mathrm{U} / L)$ & $35(24-53)$ & $60(35-80)$ & $<0.001$ \\
\hline ALAT (U/L) & $27(17-46)$ & $36(26-56)$ & $<0.05$ \\
\hline $\mathrm{LDH}(\mathrm{U} / \mathrm{I})$ & $310(244-441)$ & $503(411-703)$ & $<0.00001$ \\
\hline Lipase (U/I) & $32(19-50)$ & $38(25-53)$ & NS \\
\hline Creatine kinase $(\mathrm{U} / \mathrm{I})$ & $136(59-266)$ & $229(101-426)$ & 0.07 \\
\hline YKL-40 (ng/ml) & $186(84-384)$ & $241(172-827)$ & $<0.05$ \\
\hline
\end{tabular}

When the data follow a normal distribution, the results are expressed as mean \pm standard deviation, and otherwise, they are expressed as the median (IQR) $M$, male; F, female; NS, nonsignificant

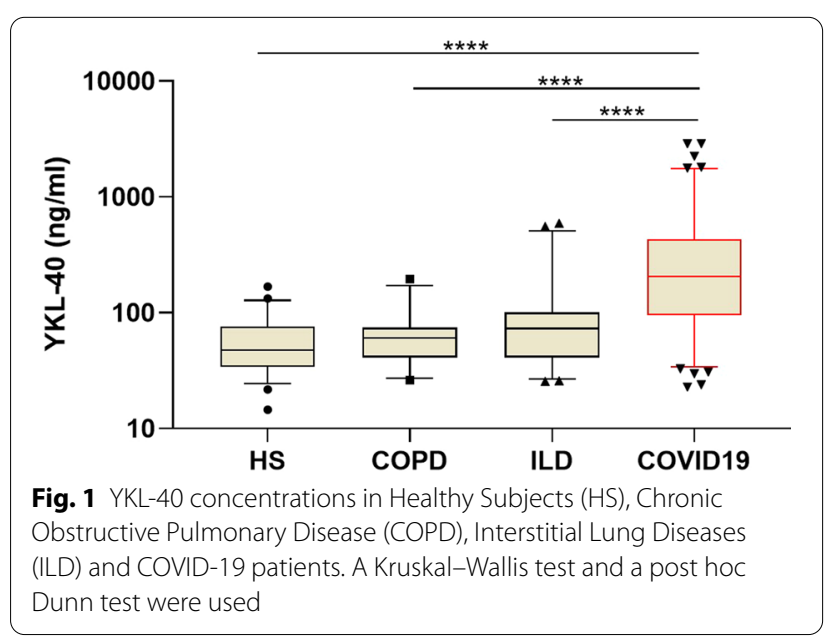

reached $0.78(p<0.0001)$. The positive predictive value was $70 \%$, and the negative predictive value was $83 \%$.

In conclusion, this study showed that firstly the COVID-19 patients had higher levels of YKL-40 compared to a control population (HS, COPD and ILD) and secondly that within the COVID-19 population YKL-40 was an indicator of the seriousness of infection since it is linked to complications such as admission to ICU, ARF or MOF. This marker could also be a predictive marker to anticipate management at the ICU and is useful for the prognosis of the onset of an ILD later. Future studies are also needed to assess the correlation between the levels of YKL-40 and pulmonary sequelae that patients with COVID-19 would develop.

\section{Abbreviations}

ICU: Intensive care unit; ILD: Interstitial lung diseases; HS: Healthy subjects; COPD: Chronic obstructive pulmonary disease; MOF: Multiple organ failure; AUC: Area under the ROC curve.

\section{Acknowledgements}

The authors would like to thank the COVID-19 clinical investigators of the CHU de Liège: Ancion, A., Berg, J., Bonhomme, O., Bouquegneau, A., Bovy, C., Bruls, S., Darcis, G., Defraigne, J.O., Ghuysen, A., Gilbert, A., Heinen, V., Lambermont, B., Louis, R., Malaise, O., Martin, M., Misset, B., Moutschen, M., Nguyen Dang, D., Piazza, J., Szecel, D., Szecel, J., Van Cauwenberge, H., Von Frenckell, C., Vroonen, L.

\section{Authors' contributions}

$\mathrm{JG}, \mathrm{EC}$ and $\mathrm{MH}$ contributed to conceptualization. LS, ANF and MH curated the data. MH contributed to formal analysis. LS and EC contributed to methodology. LS contributed to investigation and writing original draft. EC and JG contributed to supervision, validation, visualization and writing - review and editing. All authors read and approved the final manuscript.

\section{Funding}

Research grant from Fond Leon Fredericq.

\section{Availability of data and materials}

The datasets used and/or analyzed during the current study are available from the corresponding author on reasonable request.

\section{Ethics approval and consent to participate}

No specific approval was requested to the ethic committee as a leaflet including the following statement is given to all admitted patients: According to the law of the 19th December 2008, any left-over of biological material collected from patients for their standard medical management and normally destroyed when all diagnostic analyses have been performed, can be used for validation of methods. The law authorizes such use except if the patient expressed an opposition when still alive (presume consent). Written informed consent for participation was not required for this study in accordance with the national legislation and the institutional requirements. However, for HS, COPD and ILD patients, the protocol was approved by the ethics committee of $\mathrm{CHU}$ of Liège, and all subjects gave written consent before their enrollment (Belgian Number: B707201422832; ref: 2014/302).

\section{Consent for publication}

Not applicable. 


\section{Competing interests}

All authors declare to have no specific competing interests for this specific publication.

\section{Author details}

${ }^{1}$ Department of Clinical Chemistry, University of Liege, $\mathrm{CHU}$ de Liège, Domaine Universitaire du Sart-Tilman, B35, 4000 Liège, Belgium. ${ }^{2}$ Department of Pneumology, CHU de Liège, Liège, Belgium.

Received: 5 November 2020 Accepted: 9 November 2020

Published online: 16 February 2021

\section{References}

1. Korthagen NM, van Moorsel CHM, Barlo NP, Ruven HJT, Kruit A, Heron M, et al. Serum and BALF YKL-40 levels are predictors of survival in idiopathic pulmonary fibrosis. Respir Med. 2011;105:106-13.

2. Létuvé S, Kozhich A, Arouche N, Grandsaigne M, Reed J, Dombret $\mathrm{M}-\mathrm{C}$, et al. YKL-40 is elevated in patients with chronic obstructive pulmonary disease and activates alveolar macrophages. J Immunol. 2008;181:5167-73.

3. Nordenbæk C, Johansen JS, Halberg P, Wiik A, Garbarsch C, Ullman S, et al. High serum levels of YKL-40 in patients with systemic sclerosis are associated with pulmonary involvement. Scand J Rheumatol. 2005;34:293-7.

4. Inoue Y, Kaner RJ, Guiot J, Maher TM, Tomassetti S, Moiseev S, et al. Diagnostic and prognostic biomarkers for chronic fibrosing interstitial lung diseases with a progressive phenotype. Chest. 2020;158:646-59.

5. Guiot J, Moermans C, Henket M, Corhay JL, Louis R. Blood biomarkers in idiopathic pulmonary fibrosis. Lung. 2017;195:273-80.

6. Bonhomme O, André B, Gester F, De Seny D, Moermans C, Struman I, et al. Biomarkers in systemic sclerosis-associated interstitial lung disease: review of the literature. Rheumatol (United Kingdom). 2019;58:1534-46.

\section{Publisher's Note}

Springer Nature remains neutral with regard to jurisdictional claims in published maps and institutional affiliations.
Ready to submit your research? Choose BMC and benefit from:

- fast, convenient online submission

- thorough peer review by experienced researchers in your field

- rapid publication on acceptance

- support for research data, including large and complex data types

- gold Open Access which fosters wider collaboration and increased citations

- maximum visibility for your research: over $100 \mathrm{M}$ website views per year

At BMC, research is always in progress.

Learn more biomedcentral.com/submissions 